\title{
Identification of 3,6-Disubstituted Dihydropyrones as Inhibitors of Human Lactate Dehydrogenase
}

Benjamin P. Fauber, ${ }^{\mathrm{a},}$, Peter S. Dragovich ${ }^{\mathrm{a}}$, Jinhua Chen ${ }^{\mathrm{b}}$, Laura B. Corson ${ }^{\mathrm{a}}$, Charles Z. Ding ${ }^{\mathrm{b}}$, Charles Eigenbrot ${ }^{\mathrm{a}}$, Sharada Labadie ${ }^{\mathrm{a}}$, Shiva Malek ${ }^{\mathrm{a}}$, David Peterson ${ }^{\mathrm{a}}$, Hans E. Purkey ${ }^{\mathrm{a}}$, Kirk Robarge $^{\mathrm{a}}$, Steve Sideris ${ }^{\mathrm{a}}$, Mark Ultsch ${ }^{\mathrm{a}}$, BinQing Wei ${ }^{\mathrm{a}}$, Ivana Yen ${ }^{\mathrm{a}}$, Qin Yue ${ }^{\mathrm{a}}$, and Aihe Zhou ${ }^{\mathrm{a}}$

\begin{abstract}
A series of 3,6-disubstituted dihydropyrones were identified as inhibitors of human lactate dehydrogenase (LDH)-A. Structure activity relationships were explored and a series of 6,6-spiro analogs led to improvements in LDHA potency $\left(\mathrm{IC}_{50}<350 \mathrm{nM}\right)$. An X-ray crystal structure of an improved compound bound to human LDHA was obtained and it illustrated additional opportunities to enhance the potency of these compounds, resulting in the identification of $\mathbf{5 1}\left(\mathrm{IC}_{50}=30 \mathrm{nM}\right)$.
\end{abstract}

Keywords: LDHA, X-ray crystal structure, tumor metabolism.

Abnormal cellular metabolism in tumor cells is one of the emerging hallmarks of cancer. ${ }^{1}$ Tumor cells can produce ATP using an inefficient mitochondrial-independent glycolytic pathway under normoxic and hypoxic conditions, ${ }^{2}$ unlike normal tissues which typically produce ATP 
using the more effective mitochondrial tricarboxylic acid (TCA) cycle ${ }^{3}$ (also known as the Krebs cycle). Tumor cells' catabolism of glucose generates several reaction products including pyruvate and NADH. ${ }^{4}$ Pyruvate is further converted into lactate by the NADH-dependent enzyme lactate dehydrogenase (LDH)-A, thus completing the glycolytic cycle. ${ }^{5}$ Elevated lactate levels are noted across several classes of human tumors, ${ }^{6}$ indicating the potential increased activity of LDHA in cancerous tissues. Additional studies have shown that LDHA is over-expressed in human tumors. ${ }^{7}$ Cancer cell lines with increased LDHA expression exhibit a greater dependence on glycoloysis. ${ }^{8}$ Furthermore, a recent study demonstrated that the ablation of LDHA with an inducible genetic knock-out mouse was efficacious in a mouse non-small cell lung cancer (NSCLC) model. ${ }^{9}$ Collectively, these results suggest that LDHA is an attractive target for the treatment of human cancer. ${ }^{10}$

Several groups have identified LDHA inhibitors ${ }^{11}$ with some of the most potent and well characterized inhibitors originating from fragment screening campaigns. ${ }^{12}$ Our group discovered several distinct chemical classes of LDHA inhibitors ${ }^{13}$ from a high-throughput screen (HTS) of the Genentech/Roche corporate compound collection (Figure 1). ${ }^{14}$ Compounds $\mathbf{1}^{13 \mathrm{c}}$ and $\mathbf{2}^{13 \mathrm{~b}}$ were moderately potent in the LDHA biochemical assay, yet they lacked suitable in vitro and in vivo ADME properties for progression as lead series. Our recent disclosure of a 1,3-dicarbonyl compound (3) and related analogs ${ }^{13 a}$ illustrated this series' NADH non-competitive binding mode in the LDHA substrate binding site, its high ligand-efficiency (LE) ${ }^{15}$ and favorable in vivo PK properties. The 1,3-dicarbonyl motif of $\mathbf{3}$ resided in a tautomer consistent with the structure shown in Figure 1 and was ionized at physiological $\mathrm{pH}$ (measured $\mathrm{p} K_{\mathrm{a}}=2.63$ ). Furthermore, the binding mode of $\mathbf{3}$ in the LDHA X-ray co-crystal structure was consistent with the enolate 
tautomer of $\mathbf{3}$ [PDB: 4QO7]. ${ }^{13 \mathrm{a}}$ To further explore the potential of the 1,3-dicarbonyl series, we investigated other core motifs and their impact on the LDHA biochemical potency. ${ }^{16}$

A variety of core changes were introduced while holding the 3- and 6-position substituents constant (Table 1). It was noted that changing the core atom adjacent to one of the carbonyls (4-6) did not affect the LDHA biochemical potency $\left(\mathrm{IC}_{50}=4.0 \mu \mathrm{M}\right)$. Yet, these same core changes did impact the measured $\mathrm{p} K_{\mathrm{a}}$ values, apparent cellular permeability $\left(P_{a p p}\right)$ as assessed by the Madin-Darby canine kidney (MDCK) assay, ${ }^{17}$ and human plasma-protein unbound fraction. Further exploration of the 3-position linker in tandem with the aforementioned core changes led to a matrix of analogs (7-12) with the 3-position thioether being preferred for LDHA potency (4-6). We presumed that the 3-position thioether was preferred due to its ability to interact with the Arg168 residue in the LDHA substrate binding site. ${ }^{13 a, 18}$ Changes to the 3-position linker atom negatively affected this Arg168 interaction and led to diminished LDHA affinity. The loss of LDHA affinity was most pronounced in a 3-position benzylic analog (Table $1, \mathrm{X}=\mathrm{Y}=\mathrm{CH}_{2}, \mathrm{IC}_{50}>100 \mu \mathrm{M}$ ) even though the molecule could adopt an similar ligand confirmation to that of the more potent thioether analog (5). ${ }^{19}$

The identical LDHA potency values of $\mathbf{4}$ and $\mathbf{5}$ presented an opportunity to further explore the 6-position SAR of the dihydropyrone core. The initial dihydropyrone analogs were synthesized using a previously described route ${ }^{20}$ in which a benzaldehyde (13) was reacted with Weiler's dianion ${ }^{21}$ to form the dihydropyrone core $(\mathbf{1 4}$, Scheme 1). The 3-position thioether was then installed under basic conditions to yield the final compounds (15). This initial synthetic route was robust and allowed for the generation of several dihydropyrone analogs, yet it required the introduction of the 6-position substituent early in the synthesis. In an effort to introduce the 6-position substituent late in the synthesis, we devised a modified route to the dihydropyrones 
(Scheme 2). Methyl acetoacetate was subjected to 2-chloro-benzene disulfide (16) under basic conditions to produce the methyl acetoacetate $\alpha$-thioether product (17). Treatment of 17 with two equivalents of lithium diisopropyl amide, followed by the addition of an aldehyde or ketone, then subjection to alkaline cyclization conditions formed the dihydropyrone product (18).

We took advantage of the modified synthetic route to explore several 6-position analogs (Table 2) as dihydropyrone matched molecular pairs ${ }^{22}$ to the previously reported ${ }^{13 a}$ all-carbon-core analogs. The LDHA biochemical potency of the ortho-, meta-, and para-chlorophenyl 6-position analogs (19-21, respectively) were very similar to their all-carbon-core analogs, indicating comparable SAR between the two cores. There was a six-fold drop in LDHA potency when comparing the 2',6'-disubstituted analogs in the dihydropyrone core (22-23) against their matched molecular pairs in the all carbon core. This change in potency was not initially anticipated but it could be retrospectively attributed to the subtle difference in the 6-position vector between the two core types. ${ }^{23}$ The favorable potency of the ortho- and meta-substituted analogs (19 and 20) led us to explore other substituents on the 6-position arene. The cyano-substituted analogs $\mathbf{2 4}$ and $\mathbf{2 5}$ were less potent than the chloro-substituted matched molecular pairs, and the ethoxy substitution (26-27) provided only a slight improvement in potency at the meta-position ( $\mathrm{LDHA} \mathrm{IC}_{50}=2.2 \mu \mathrm{M}$ ) over the parent molecule (4). Replacement of the 6-position phenyl ring with a variety of alkyl and aliphatic heterocycles (exemplified by $\mathbf{2 8 - 2 9}$ ) was poorly tolerated (LDHA $\mathrm{IC}_{50}>100 \mu \mathrm{M}$ ). Exploration of 6-position heterocyclic aromatic groups revealed detectable LHDA potency for the methylated pyrazole (30) and pyrimidine analogs (31), whereas the 2-pyridyl (32) was the most potent (LDHA IC $\left._{50}=3.5 \mu \mathrm{M}\right)$ of all the pyridine isomers (32-34). Compound 32 was equipotent to 4 in the LDHA biochemical assay, yet 32 was less lipophilic (as assessed by the cLogP) ${ }^{24}$ and 
possessed an improved ligand-lipophilic efficiency $(L L E)^{25}$ value $(L L E=3.7)$ compared to 4 $(\operatorname{LLE}=2.4)$.

To further explore the 6-position SAR, we investigated 6,6-disubstituted dihydropyrone analogs (Table 3) using the LDHA co-crystal structure of 4 [PDB: 4QO7] ${ }^{13 a}$ to guide our designs. Based on this co-structure, we assumed that the 6-position phenyl ring would sit in an axial orientation on the dihydropyrone core and the additional 6-position substituent would access the equatorial vector. ${ }^{26}$ The 6-position methyl group (35) was tolerated and equipotent to 4, whereas the cyclopropyl group was less potent (36) (LDHA $\mathrm{IC}_{50}=13 \mu \mathrm{M}$ ). Using structure-based drug design principles and docking studies, we envisioned adding substituents along the same vector as the methyl group on $\mathbf{3 5}$ to engage the nearby Thr247 or 3'-hydroxyl group of the NADH ribose in a hydrophilic interaction. The introduction of a 6-position hydroxymethyl moiety (37), carboxylic acid (38), and primary amide (39) provided analogs with modest LDHA biochemical potency but no further improvements beyond 35 . The secondary amide analog (40) was equipotent to the primary amide (39), whereas the tertiary amide (41) was less potent. Based on these results, we concluded that there were some steric requirements to maintain potency in this region yet there were no notable improvements in the ligand affinities. Homologation of $\mathbf{4 0}$ to a methylene-spaced secondary amide analog (42) diminished the LDHA affinity. Additional directly-linked and methylene-spaced 6-position amide analogs were explored (data not shown), and none provided improvements in potency over the parent methyl compound (35).

The limited success in identifying potent substituted 6-aryl and 6,6-disubstituted dihydropyrone analogs led us to revisit the axially-oriented 6-aryl analogs that were identified in our earlier work. ${ }^{13 a}$ We envisioned that we could force the 6-position phenyl into an axial 
orientation on the dihydropyrone scaffold with a spirocyclic ring system. These spirocyclic analogs were synthesized using the route described in Scheme 2 and the corresponding indanone and tetralone reagents. The resulting spirocyclic products were separated into single unknown stereoisomers and tested as single enantiomers, with one enantiomer typically 6-to-20-fold more potent that the other enantiomer (Table 4). The favored enantiomers of the 4',4'-linked dihydrochromene (43) and the 1',1'-linked tetralin (45) analogs were essentially equipotent to the parent molecule (4), with 45 displaying the best LDHA potency $\left(\mathrm{IC}_{50}=2.1 \mu \mathrm{M}\right)$. Exploration of the 1 ',1'-linked indane (47) led to an approximate 10-fold improvement in LDHA potency $\left(\mathrm{IC}_{50}=360 \mathrm{nM}\right)$ over $\mathbf{4 5}$.

To further explain the improved potency of 47 , we obtained a $1.91 \AA$ resolution co-crystal structure of $\mathbf{4 7}$ bound to human LDHA in the presence of NADH [PDB: 4RLS]. ${ }^{27}$ As shown in Figure 2, the dihydropyrone core of $\mathbf{4 7}$ bound to LDHA in a similar confirmation to the related all-carbon-core analogs previously reported by our group. ${ }^{13 a}$ Based on the proximity of hydrogen bonding residues near the ligand, we determined that the ester oxygen of the dihydropyrone core formed a hydrogen bond ${ }^{28}$ with Thr247 (2.9 $\left.\mathrm{A}\right)$. This conformation of the core was most sensible given that the other enantiomer would create a clash between the methylene on the ligand's core and the hydroxyl group of Thr247. This observation also allowed us to establish the absolute stereochemistry of $\mathbf{4 7}$ as the $(R)$-configuration at the 6-position of the dihydropyrone core. One of the carbonyl groups on the dihydropyrone core engaged the neighboring His 192 residue in a hydrogen bond (2.6 ̊), and His192 was further stabilized by a hydrogen bond network with the nearby Asp165 (2.7-3.1 $)$. As noted with the prior all-carbon ligand LDHA co-crystal structures from our group, ${ }^{13 a}$ the thioether and remaining carbonyl 
moiety on the dihydropyrone core engaged Arg168 in a bidentate hydrogen bonding interaction (2.6-3.1 ̊).

The solvent accessible surface for the LDHA co-structure of 47 revealed some opportunities for additional substitution at the 7'-position of the indane group. The 7'-position pointed toward the so-called "100's loop" region of the protein where we and others have observed side-chain and backbone mobility. ${ }^{11-13}$ The 7'-position vector would also allow us to target an interaction with Ile241 (Figure 2). A previous publication from our group ${ }^{13 b}$ demonstrated that a hydrophobic interaction with Ile241 in the LDHA substrate binding pocket can lead to improvements in potency. Thus, we synthesized a (7'-Br)indane analog, and the favored enantiomer (49) was equipotent with 47. This result confirmed our hypothesis that there was an opportunity to add substituents using this vector. Compound 49 was subjected to Suzuki-Miyaura cross-coupling conditions ${ }^{29}$ to provide the (7'-phenyl)indane analogs. The favored enantiomer of the (7'-phenyl)indane (51) was a very potent biochemical inhibitor of LDHA $\left(\mathrm{IC}_{50}=30 \mathrm{nM}\right)$. Although 51 was fairly lipophilic $(\operatorname{cog} \mathrm{P}=5.0)$, the LLE and LE values of $51(\mathrm{LLE}=2.5, \mathrm{LE}=0.35)$ were comparable to 4 . Compound 51 also represented the first example in which we successfully merged the SAR of the dihydropyrone series with the favored ligand-protein interactions observed with our previously described 2-aminopyrazine series (exemplified by 2$){ }^{13 b}$

Compound $\mathbf{5 1}$ was profiled against a panel of in vitro ADME assays. The molecule was very soluble in $\mathrm{pH} 7.4$ buffered aqueous solution (kinetic solubility $=169 \mu \mathrm{M}$ ). The compound had low MDCK cell permeability $\left(P_{a p p(\mathrm{~A} \rightarrow \mathrm{B})}=1.610^{-6} \mathrm{~cm} / \mathrm{s}\right)$ and it was also highly bound to human and rodent plasma proteins (<1\% free in both species). When $\mathbf{5 1}$ was incubated with human and rat liver microsomes, we observed high and moderate hepatic clearance $\left(\mathrm{Cl}_{\text {hep }}\right)$ 
values, respectively $\left(\mathrm{Cl}_{\text {hep }}=20\right.$ and $41 \mathrm{~mL} / \mathrm{min} / \mathrm{kg}$, respectively). The high plasma-protein binding, low $P_{a p p}$, and high-to-moderate in vitro $\mathrm{Cl}_{\text {hep }}$ values were presumably due to the lipophilicity of $\mathbf{5 1} .^{30}$

We also assessed the ability of $\mathbf{5 1}$ to inhibit the production of lactate in MCF7 cells. ${ }^{16}$ No dose-response was observed in the assay at the highest compound concentration of $50 \mu \mathrm{M}$ under standard serum conditions $\left(\mathrm{EC}_{50}>50 \mu \mathrm{M}\right)$. When the $\mathrm{MCF} 7$ cellular assay was conducted in the absence of serum we observed a reduction in lactate production with no effect on cell viability $\left(\mathrm{EC}_{50}=32 \mu \mathrm{M}\right)$. This result illustrated that the weak cellular potency of $\mathbf{5 1}$ was potentially related to insufficient biochemical potency and/or high plasma-protein binding. We committed substantial efforts toward improving these two parameters and they will be the focus of future disclosures.

In summary, we identified a new class of 3,6-disubstituted dihydropyrone LDHA inhibitors. The synthesis of 6-substituted and 6,6-disubstituted dihydropyrone analogs led to limited potency improvements, whereas the 6,6-spirocyclic analogs led to a potency breakthrough as exemplified by compound 47. The co-crystal structure of LDHA with $\mathbf{4 7}$ illustrated additional opportunities for improving the ligand affinity and these were realized with the synthesis of $\mathbf{5 1}$ as a potent inhibitor of human LDHA. 


\section{Acknowledgements}

We thank Dr. Peter Jackson for many helpful discussions regarding LDHA. In addition, we thank J. L. Stillwell and Crystallographic Consulting, Ltd. for diffraction data collection. Use of the Stanford Synchrotron Radiation Lightsource was supported by the U.S. Department of Energy, Office of Science (BES), under Contract No. DE-AC02-76SF00515. The SSRL Structural Molecular Biology Program was supported by the DOE Office of Biological and Environmental Research, and by the National Institutes of Health, National Institute of General Medical Sciences (including P41GM103393).

\section{Supplementary data}

Supplementary data associated with this article can be found in the online version at http:// INSERT URL HERE 


\section{References and notes}

1. (a) Ward, P. S.; Thompson, C. B. Cancer Cell 2012, 21, 297; (b) Hanahan, D.; Weinberg, R. A. Cell 2011, 144, 646.

2. Vander Heiden, M. G.; Cantley, L. C.; Thompson, C. B. Science 2009, 324, 1029.

3. Warburg, O. Science 1956, 123, 309.

4. Galluzzi, L.; Kepp, O.; Vander Heiden, M. G.; Kroemer, G. Nat. Rev. Drug Disc. 2013, 12,829 .

5. Salaway, J. G. Metabolism at a Glance, $3^{\text {rd }}$ Ed.; Blackwell Publishing: Malden, 2004, pp10-25.

6. Hirschhaeuser, F.; Sattler, U. G. A.; Mueller-Klieser, W. Cancer Res. 2011, 71, 6921.

7. (a) Balinsky, D.; Platz, C. E.; Lewis, J. W. Cancer Res. 1983, 43, 5895; (b) Goldman, R. D.; Kaplan, N. O.; Hall, T. C. Cancer Res. 1964, 24, 389.

8. Fantin, V. R.; St-Pierre, J.; Leder, P. Cancer Cell 2006, 9, 425.

9. Xie, H.; Hanai, J.-I.; Ren, J.-G.; Kats, L.; Burgess, K.; Bhargava, P.; Signoretti, S.; Billiard, J.; Duffy, K. J.; Grant, A.; Wang, X.; Lorkiewicz, P. K.; Schatzman, S.; Bousamra, M.; Lane, A. N.; Higashi, R. M; Fan, T. W. M.; Pandolfi, P. P.; Sukhatme, V. P.; Seth, P. Cell Metabolism 2014, 19, 1.

10. (a) Vander Heiden, M. G. Nat. Rev. Drug Disc. 2011, 10, 671; (b) Tennant, D. A.; Durán, R. V.; Gottlieb, E. Nat. Rev. Cancer 2010, 10, 267.

11. (a) Calvaresi, E. C.; Granchi, C.; Tuccinardi, T.; Di Bussolo, V.; Huigens, R. W.; Lee, H. Y.; Palchaudhuri, R.; Macchia, M.; Martinelli, A.; Minutolo, F.; Hergenrother, P. J. ChemBioChem 2013, 14, 2263; (b) Billiard, J.; Dennison, J. B.; Briand, J.; Annan, R. S.; Chai, D.; Colón, M.; Dodson, C. S.; Gilbert, S. A.; Greshock, J.; Jing, J.; Lu, H.; 
McNulty, D.; McSurdy-Freed, J. E.; Orband-Miller, L. A.; Mills, G. B.; Quinn, C. J.; Schneck, J. L.; Scott, G. F.; Shaw, A. N.; Waitt, G.; Wooster, R. F.; Duffy, K. J. Cancer Metab. 2013, 1, 19; (c) Granchi, C.; Roy, S.; De Simone, A.; Salvetti, I.; Tuccinardi, T.; Martinelli, A.; Macchia, M.; Lanza, M.; Betti, L.; Gianniccini, G.; Lucacchini, A.; Giovannetti, E.; Sciarrillo, R.; Peters, G. J.; Minutolo, F. Eur. J. Med. Chem. 2011, 46, 5398; (d) Granchi, C.; Roy, S.; Giacomelli, C.; Macchia, M.; Tuccinardi, T.; Martinelli, A.; Lanza, M.; Betti, L.; Gianniccini, G.; Lucacchini, A.; Funel, N.; León, L. G.; Giovannetti, E.; Peters, G. J.; Palchaudhuri, R.; Calvaresi, E. C.; Hergenrother, P. J.; Minutolo, F. J. Med. Chem. 2011, 54, 1599; (e) Granchi, C.; Bertini, S.; Macchia, M; Minutolo, F. Curr. Med. Chem. 2010, 17, 672; (f) Le, A.; Cooper, C. R.; Gouw, A. M.; Dinavahi, R.; Maitra, A.; Deck, L. M.; Royer, R. E.; Vander Jagt, D. L.; Semenza, G. L.; Dang, C. V. Proc. Natl. Acad. Sci. 2010, 107, 2037.

12. (a) Kohlmann, A.; Zech, S. G.; Li, F.; Zhou, T.; Squillace, R. M.; Commodore, L.; Greenfield, M. T.; Lu, X.; Miller, D. P.; Huang, W.-S.; Qi, J.; Thomas, R. M.; Wang, Y.; Zhang, S.; Dodd, R.; Liu, S.; Xu, R.; Xu, Y.; Miret, J. J.; Rivera, V.; Clarckson, T.; Shakespeare, W. C.; Zhu, X.; Dalgarno, D. C. J. Med. Chem. 2013, 56, 1023; (b) Ward, R. A.; Brassington, C.; Breeze, A. L.; Caputo, A.; Critchlow, S.; Davies, G.; Goodwin, L.; Hassall, G.; Greenwood, R.; Holdgate, G. A.; Mrosek, M.; Norman, R. A.; Pearson, S.; Tart, J.; Tucker, J. A.; Vogtherr, M.; Whittaker, D.; Wingfield, J.; Winter, J.; Hudson, K. J. Med. Chem. 2012, 55, 3285.

13. (a) Dragovich, P. S.; Fauber, B. P.; Boggs, J.; Chen, J.; Corson, L. B.; Ding, C. Z.; Eigenbrot, C.; Ge, H.; Giannetti, A. M.; Hunsaker, T.; Labadie, S.; Li, C.; Liu, Y.; Liu, Y.; Ma, S.; Malek, S.; Peterson, D.; Pitts, K. E.; Purkey, H. E.; Robarge, K.; Salphati, L.; 
Sideris, S.; Ultsch, M.; VanderPorten, E.; Wang, J.; Wei, B.; Xu, Q.; Yen, I.; Yue, Q.; Zhang, H.; Zhang, X.; Zhou, A. Bioorg. Med. Chem. Lett. 2014, 24, 3764; (b) Fauber, B. P.; Dragovich, P. S.; Chen, J.; Corson, L. B.; Ding, C. Z.; Eigenbrot, C.; Giannetti, A. M.; Hunsaker, T.; Labadie, S.; Liu, Y.; Liu, Y.; Malek, S.; Peterson, D.; Pitts, K.; Sideris, S.; Ultsch, M.; VanderPorten, E.; Wang, J.; Wei, B.; Yen, I.; Yue, Q. Bioorg. Med. Chem. Lett. 2013, 23, 5533; (c) Dragovich, P. S.; Fauber, B. P.; Corson, L. B.; Ding, C. Z.; Eigenbrot, C.; Ge, H.; Giannetti, A. M.; Hunsaker, T.; Labadie, S.; Liu, Y.; Malek, S.; Pan, B.; Peterson, D.; Pitts, K.; Purkey, H. E.; Sideris, S.; Ultsch, M.; VanderPorten, E.; Wei, B.; Xu, Q.; Yen, I.; Yue, Q.; Zhang, H.; Zhang, X. Bioorg. Med. Chem. Lett. 2013, $23,3186$.

14. VanderPorten, E.; Frich, L.; Turincio, R.; Thana, P.; LaMarr, W.; Liu, Y. Anal. Biochem. 2013, 441, 115.

15. (a) Murray, C. W.; Erlanson, D. A.; Hopkins, A. L.; Keserü, G. M.; Leeson, P. D.; Rees, D. C.; Reynolds, C. H.; Richmond, N. J. ACS Med. Chem. Lett. 2014, 5, 616; (b) Hopkins, A. L.; Keserü, G. M.; Leeson, P. D.; Rees, D. C.; Reynolds, C. H. Nat. Drug Disc. 2014, 13, 105; (c) Hopkins, A. L.; Groom, C. R.; Alex, A. Drug Disc. Today 2004, $9,430$.

16. See the Supplementary Data sections of Ref. 13c and 13b for details regarding the enzyme and cell assay methods, respectively.

17. Irvine, J. D.; Takahashi, L.; Lockhart, K.; Cheong, J.; Tolan, J. W.; Selick, H. E.; Grove, J. R. J. Pharm. Sci. 1999, 88, 28.

18. Examples of thioethers that formed non-covalent interactions with arginine or guanidinium groups can be found in both the PDB (i.e. 4IJL) and the CSD (i.e. 
GUYTEZ). Thioethers are known to form non-bonded sulfur-nitrogen and sulfur-oxygen interactions. For additional details, see: (a) Honda, T.; Tajima, H.; Kaneko, Y.; Ban, M.; Inaba, T.; Takeno, Y.; Okamoto, K.; Aono, H. Bioorg. Med. Chem. Lett. 2008, 18, 2939; (b) Nagao, Y.; Hirata, T.; Goto, S.; Sano, S.; Kakehi, A.; Iizuka, K.; Shiro, M. J. Am. Chem. Soc. 1998, 120, 3104; (c) Ohkata, K.; Ohsugi, M.; Yamamoto, K.; Ohsawa, M.; Akiba, K. J. Am. Chem. Soc. 1996, 118, 6355.

19. Li, H.; Linton, A.; Tatlock, J.; Gonzalez, J.; Borchardt, A.; Abreo, M.; Jewell, T.; Patel, L.; Drowns, M.; Ludlum, S.; Goble, M.; Yang, M.; Blazel, J.; Rahavendran, R.; Skor, H.; Shi, S.; Lewis, C.; Fuhrman, S. J. Med. Chem. 2007, 50, 3969.

20. Vara Prasad, J. V. N.; Boyer, F. E.; Domagala, J. M.; Ellsworth, E. L.; Gajda, C.; Hamilton, H. W.; Hagen, S. E.; Markoski, L. J.; Steinbaugh, B. A.; Tait, B. D.; Humblet, C.; Lunney, E. A.; Pavlovsky, A.; Rubin, J. R.; Ferguson, D.; Graham, N.; Holler, T.; Hupe, D.; Nouhan, C.; Tummino, P. J.; Urumov, A.; Zeikus, E.; Zeikus, G.; Gracheck, S. J.; Saunders, J. M.; VanderRoest, S.; Brodfuehrer, J.; Iyer, K.; Sinz, M.; Gulnik, S. V.; Erickson, J. W. Bioorg. Med. Chem. 1999, 7, 2775.

21. Huckin, S. N.; Weiler, L. J. Am. Chem. Soc. 1974, 96, 1082.

22. Dossetter, A. G.; Griffen, E. J.; Leach, A. G. Drug Disc. Today 2013, 18, 724.

23. Conformational analyses were conducted using the "Minimize" tool (MMFF94x) within the MOE (Molecular Operating Environment) software package from Chemical Computing Group (Montreal, Quebec, Canada).

24. The partition coefficient (cLogP) was calculated with internal software using the VolSurf approach. For additional details, see: Cruciani, G.; Crivori, P.; Carrupt, P.-A.; Testa, B. J. Mol. Struc.-Theochem 2000, 503, 17. 
25. (a) Leeson, P. D.; Springthorpe, B. Nat. Rev. Drug Discov. 2007, 6, 881; (b) Leach, A. R.; Hann, M. M.; Burrows, J. N.; Griffen, E. J. Mol. BioSyst. 2006, 2, 429.

26. Additive conformational free energies are not predictive for the conformational preferences of geminal substituted six-membered rings. It is often challenging to find agreement between the calculated and experimental conformational free energies for such systems. For additional details, see: (a) Wiberg, K. B.; Castejon, H.; Bailey, W. F.; Ochterski, J. J. Org. Chem. 2000, 65, 1181; (b) Eliel, E. L.; Enanoza, R. M. J. Am. Chem. Soc. 1972, 94, 8072.

27. See the Supplementary Data for experimental details associated with the described co-crystal structure. All crystallographic descriptions are based on analysis of the ligand chain ' $\mathrm{W}$ '/protein chain ' $\mathrm{D}$ ' LDHA protomer within the tetrameric asymmetric unit. Electron density corresponding to lactate was noted in protein chains ' $\mathrm{B}$ ' and ' $\mathrm{C}$.' Fragmented electron density was noted within the substrate binding site of protein chain 'A.' See the deposited PDB file for additional structural details [PDB: 4RLS].

28. Bissantz, C.; Kuhn, B.; Stahl, M. J. Med. Chem. 2010, 53, 5061.

29. Miyaura, N. Mechanistic Aspects of Metal-Catalyzed Cross-Coupling Reactions of Organoboron Compounds with Organic Halides. In Metal-Catalyzed Cross-Coupling Reactions, $2^{\text {nd }}$ ed.; de Meijere, A., Diederich, F., Eds.; Wiley-VCH Verlag GmbH \& Co. KGaA: Weinheim, 2004; Vol. 1, pp 41-123.

30. Waring, M. J. Expert Opin. Drug Discov. 2010, 5, 235. 
Figure 1. LDHA inhibitors identified by HTS campaigns at Genentech.
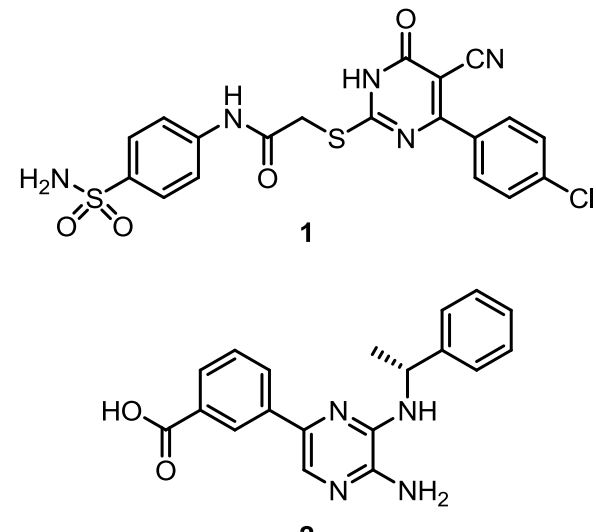

2<smiles>O=C1CC(c2ccccc2)CC(O)=C1Sc1ccccc1[N+](=O)[O-]</smiles> 
Table 1. Structure-activity relationships of the 1- and 3-positions of the 3,6-disubstituted cores.<smiles>[Y]C1=C([Y])C(O)=C[C@H](c2ccccc2)C1=O</smiles>

\begin{tabular}{|c|c|c|c|c|c|c|}
\hline Compd & $\mathbf{X}$ & $\mathbf{Y}$ & $\begin{array}{c}\text { LDHA } \\
\mathbf{I C}_{50}{ }^{2} \\
(\boldsymbol{\mu M})\end{array}$ & $\mathbf{p} \boldsymbol{K}_{\mathbf{a}}{ }^{b}$ & $\begin{array}{c}\text { MDCK } \\
\text { Permeability } \\
\mathbf{A} \rightarrow \mathbf{B} / \mathbf{B} \rightarrow \mathbf{A} \\
\left(\mathbf{1 0}^{-6} \mathbf{c m} / \mathbf{s}\right)\end{array}$ & $\begin{array}{c}\text { Human / Rat } \\
\text { Plasma-Protein } \\
\text { Binding } \\
\text { (\%unbound) }\end{array}$ \\
\hline $\mathbf{4}$ & $\mathrm{O}$ & $\mathrm{S}$ & 4.0 & 2.4 & $3 / 5$ & $0.8 / 0.8$ \\
\hline $\mathbf{5}$ & $\mathrm{CH}_{2}$ & $\mathrm{~S}$ & 4.0 & 3.0 & $12 / 18$ & $0.1 / 0.2$ \\
\hline $\mathbf{6}$ & $\mathrm{NH}$ & $\mathrm{S}$ & 4.0 & 4.1 & $7 / 9$ & $0.3 / 0.6$ \\
\hline $\mathbf{7}$ & $\mathrm{O}$ & $\mathrm{O}$ & 11 & 3.4 & $4 / 6$ & $0.6 / 1.3$ \\
\hline $\mathbf{8}$ & $\mathrm{CH}_{2}$ & $\mathrm{O}$ & 26 & 3.7 & $11 / 16$ & $1.1 / 1.2$ \\
\hline $\mathbf{9}$ & $\mathrm{NH}$ & $\mathrm{O}$ & 11 & 5.3 & $11 / 12$ & $2.2 / 2.3$ \\
\hline $\mathbf{1 0}$ & $\mathrm{O}$ & $\mathrm{NH}$ & 13 & 4.2 & $8 / 10$ & $\mathrm{ND}$ \\
\hline $\mathbf{1 1}$ & $\mathrm{CH}$ & $\mathrm{NH}$ & 25 & 4.6 & $4 / 10$ & $\mathrm{ND}$ \\
\hline $\mathbf{1 2}$ & $\mathrm{NH}$ & $\mathrm{NH}$ & 66 & 6.0 & $19 / 30$ & $\mathrm{ND}$ \\
\hline
\end{tabular}

All assay results are reported as the geometric mean of at least two separate runs. ND = not determined. ${ }^{a}$ Human LDHA biochemical inhibition. ${ }^{b}$ Measured $\mathrm{p} K_{\mathrm{a}}$ value. ${ }^{c}$ Madin-Darby canine kidney (MDCK) cell permeability assay to assess membrane permeability properties. ${ }^{17}$ 
Table 2. Structure-activity relationships of the 6-position group on 3,6-disubstituted dihydropyrones.<smiles>[R]C1CC(O)=C(Sc2ccccc2Cl)C(=O)O1</smiles>

\begin{tabular}{|c|c|c|c|c|}
\hline Compd & R-group & $\begin{array}{l}\text { LDHA } \\
I_{50}^{a} \\
(\mu \mathrm{M})\end{array}$ & $\begin{array}{l}\text { LDHA } \\
\text { LLE }^{b}\end{array}$ & cLogP \\
\hline 19 & (2-Cl)Ph & 5.5 & 1.7 & 3.6 \\
\hline 20 & $(3-\mathrm{Cl}) \mathrm{Ph}$ & 3.9 & 1.6 & 3.8 \\
\hline 21 & $(4-\mathrm{Cl}) \mathrm{Ph}$ & 16 & 1.0 & 3.8 \\
\hline 22 & (2,6-dichloro)Ph & 5.0 & 1.0 & 4.3 \\
\hline 23 & (2,6-dimethyl)Ph & 17 & 0.9 & 3.9 \\
\hline 24 & $(2-\mathrm{CN}) \mathrm{Ph}$ & $>100$ & - & 2.8 \\
\hline 25 & $(3-\mathrm{CN}) \mathrm{Ph}$ & 9.5 & 2.2 & 2.8 \\
\hline 26 & (2-OEt)Ph & 3.8 & 2.0 & 3.4 \\
\hline 27 & (3-OEt)Ph & 2.2 & 2.0 & 3.6 \\
\hline 28 & $i-\operatorname{Pr}$ & $>100$ & - & 2.9 \\
\hline 29 & 4-THP & $>100$ & - & 2.3 \\
\hline 30 & 3-(1-Me-pyrazole) & 35 & 3.0 & 1.5 \\
\hline 31 & 5-pyrimidyl & 73 & 2.9 & 1.2 \\
\hline 32 & 2-pyridyl & 3.5 & 3.7 & 1.8 \\
\hline 33 & 3-pyridyl & 15 & 2.9 & 1.9 \\
\hline 34 & 4-pyridyl & 43 & 2.5 & 1.9 \\
\hline
\end{tabular}

All assay results are reported as the geometric mean of at least two separate runs. ${ }^{a}$ Human LDHA biochemical inhibition. ${ }^{b}$ Ligand-lipophilicity efficiency (LLE) ${ }^{25}$ was calculated using the LDHA biochemical $\mathrm{IC}_{50}$ and calculated $\log \mathrm{P}(\mathrm{cLogP})^{24}$ values. 
Table 3. Structure-activity relationships at the 6-position of 3,6-disubstituted dihydropyrones.<smiles>[R]C1(c2ccccc2)CC(O)=C(Sc2ccccc2Cl)C(=O)O1</smiles>

\begin{tabular}{|c|c|c|c|c|}
\hline Compd & R-group & $\begin{array}{c}\text { LDHA } \\
I{ }^{a} \\
(\mu \mathrm{M})\end{array}$ & $\begin{array}{l}\text { LDHA } \\
\text { LLE }^{b}\end{array}$ & cLogP \\
\hline 35 & $\mathrm{Me}$ & 4.1 & 2.2 & 3.2 \\
\hline 36 & $c-P r$ & 13 & 1.4 & 3.5 \\
\hline 37 & $\mathrm{CH}_{2} \mathrm{OH}$ & 5.6 & 3.3 & 2.0 \\
\hline 38 & $\mathrm{CO}_{2} \mathrm{H}$ & 46 & 1.9 & 2.4 \\
\hline 39 & $\mathrm{CONH}_{2}$ & 6.6 & 3.6 & 1.6 \\
\hline 40 & CONHMe & 7.4 & 3.1 & 2.0 \\
\hline 41 & $\mathrm{CONMe}_{2}$ & 22 & 2.4 & 2.3 \\
\hline 42 & $\mathrm{CH}_{2} \mathrm{CONHMe}$ & 59 & 2.4 & 1.8 \\
\hline
\end{tabular}

All assay results are reported as the geometric mean of at least two separate runs. ${ }^{a}$ Human LDHA biochemical inhibition. ${ }^{b}$ Ligand-lipophilicity efficiency (LLE) ${ }^{25}$ was calculated using the LDHA biochemical $\mathrm{IC}_{50}$ and calculated $\log \mathrm{P}(\mathrm{cLogP})^{24}$ values. 
Table 4. Structure-activity relationships of 6-spiro analogs of the 3,6-disubstituted dihydropyrones.<smiles>[R]c1cccc2c1CC1(O)C(O)=C(Sc3ccccc3Cl)C(=O)OC21CC</smiles>

\begin{tabular}{|c|c|c|c|c|c|c|c|}
\hline Compd & $\mathbf{R}$ & $\mathbf{X}$ & $\mathbf{n}$ & Enantiomer $^{a}$ & $\begin{array}{l}\text { LDHA } \\
I_{b 0} \\
(\mu \mathrm{M})\end{array}$ & $\begin{array}{l}\text { LDHA } \\
\text { LLE }^{c}\end{array}$ & cLogP \\
\hline 43 & $\mathrm{H}$ & $\mathrm{O}$ & 1 & $A$ & 3.3 & 2.8 & 2.7 \\
\hline 44 & $\mathrm{H}$ & $\mathrm{O}$ & 1 & $B$ & 28 & 1.9 & 2.7 \\
\hline 45 & $\mathrm{H}$ & $\mathrm{CH}_{2}$ & 1 & $A$ & 2.1 & 2.2 & 3.5 \\
\hline 46 & $\mathrm{H}$ & $\mathrm{CH}_{2}$ & 1 & $B$ & 22 & 1.2 & 3.5 \\
\hline 47 & $\mathrm{H}$ & $\mathrm{CH}_{2}$ & 0 & $A$ & 0.36 & 3.1 & 3.1 \\
\hline 48 & $\mathrm{H}$ & $\mathrm{CH}_{2}$ & 0 & $\mathrm{~B}$ & 2.6 & 1.5 & 3.1 \\
\hline 49 & $\mathrm{Br}$ & $\mathrm{CH}_{2}$ & 0 & $A$ & 0.35 & 2.6 & 3.9 \\
\hline 50 & $\mathrm{Br}$ & $\mathrm{CH}_{2}$ & 0 & $B$ & 2.1 & 1.8 & 3.9 \\
\hline 51 & $\mathrm{Ph}$ & $\mathrm{CH}_{2}$ & 0 & $A$ & 0.030 & 2.5 & 5.0 \\
\hline 52 & $\mathrm{Ph}$ & $\mathrm{CH}_{2}$ & 0 & $\mathrm{~B}$ & 0.61 & 1.2 & 5.0 \\
\hline
\end{tabular}

All assay results are reported as the geometric mean of at least two separate runs. ${ }^{a}$ Compounds were separated into single unknown stereoisomers and identified as enantiomer A and B. ${ }^{b}$ Human LDHA biochemical inhibition. ${ }^{c}$ Ligand-lipophilicity efficiency (LLE) ${ }^{25}$ was calculated using the LDHA biochemical $\mathrm{IC}_{50}$ and calculated $\log \mathrm{P}(\mathrm{cLogP})^{24}$ values. 
Figure 2. A $1.91 \AA$ resolution co-structure of $\mathbf{4 7}$ (yellow) in complex with LDHA (grey) in the presence of NADH (orange) [PDB: 4RLS]. Hydrogen bonds are dashed lines (black). The side-chain residues and water molecules have been omitted for clarity. Compound $\mathbf{4 7}$ formed hydrogen bonds with His192 (2.6 ̊), Thr247 (2.9 ̊), and a bidentate hydrogen bond with $\operatorname{Arg} 168(2.6-3.1 \AA)$.

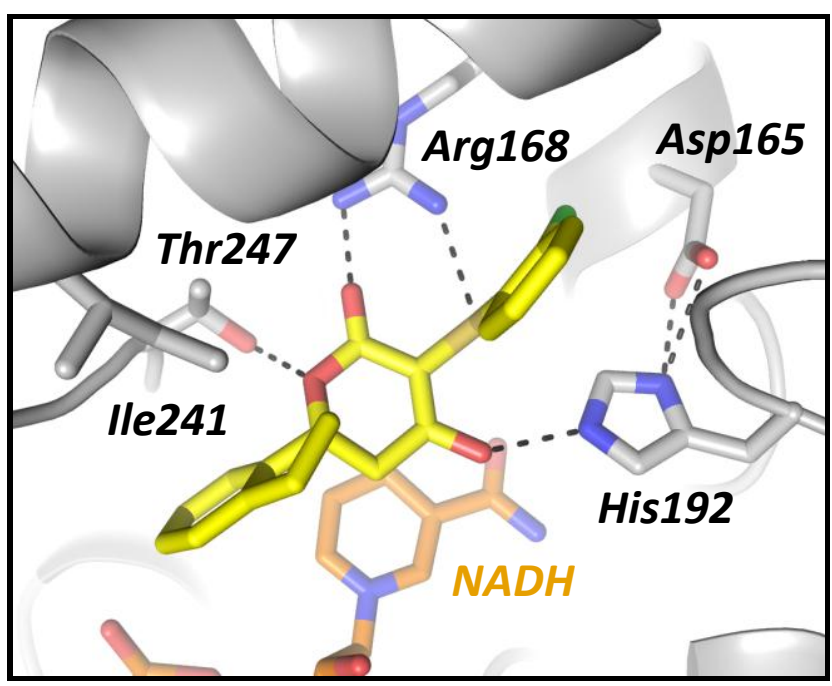


Graphical Abstract.
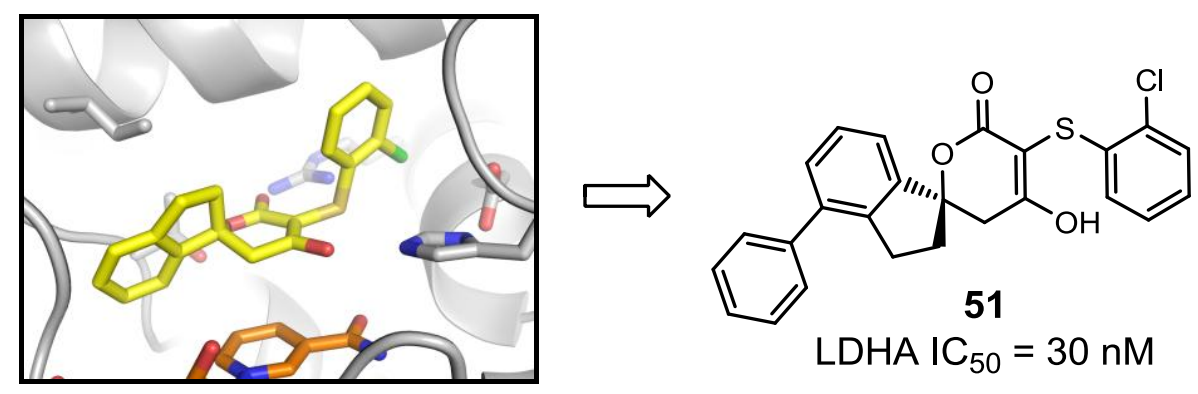